\title{
Wine Produced From Fermentation of Honey Slurry and Dates Palm Fruit Juice Blend Using Saccharomyces cerevisiae Isolated From Palm Wine
}

\author{
S. S. D. Mohammed ${ }^{1}$, B. Yohanna ${ }^{1}$, J. R. Wartu ${ }^{1}$, N. L. Abubakar ${ }^{1} \&$ S. Bello ${ }^{2}$ \\ ${ }^{1}$ Department of Microbiology, Faculty of Science, Kaduna State University, Kaduna, Nigeria \\ ${ }^{2}$ Department of Food Technology, College of Science and Technology, Kaduna Polytechnic, Nigeria \\ Correspondence: S. S. D. Mohammed, Department of Microbiology, Faculty of Science, Kaduna State University, \\ Kaduna, Nigeria. Tel: 234-080-3586-1774. E-mail: mosada78@gmail.com, mohammed.sambo@kasu.edu.ng
}

Received: April 25, 2018

Accepted: June 22, 2018

Online Published: June 26, 2018

doi:10.5539/ijb.v10n3p52

URL: https://doi.org/10.5539/ijb.v10n3p52

\begin{abstract}
This study aimed at evaluating the fermentative performance of Saccharomyces cerevisiae isolated from palm wine on honey slurry and dates palm fruit juice blend for wine production. The yeast was isolated from palm wine on saboraud dextrose agar (SDA) using pour plate technique and was identified using microscopic and standard biochemical techniques. Physicochemical parameters were determined during 21 days fermentation using standard procedures. The proximate composition of the blend before fermentation and the produced wine was evaluated. The microbiological and sensory evaluations of the produced wine was investigated. The yeast strain was identified as Saccharomyces cerevisiae. The fermentation recorded total viable yeast count from $2.5 \times 10^{6}$ to $13.0 \times 10^{6}$ $\mathrm{CFU} / \mathrm{mL}$. The physicochemical parameters revealed that during the fermentation, the $\mathrm{pH}$ values ranged from 4.3 to 5.4, percentage titratable acidity (TTA) ranged from 5.2 to 9.4. The temperature of the fermentation ranged from 24 to $29^{\circ} \mathrm{C}$ and the specific gravity values decreased steadily from 1.100 to1.010. Proximate composition of the date fruit revealed low protein content between 1.00 and 1.05 , but high moisture content $(82.43 \%)$. The produced wine contained reasonable amount of total carbohydrate A (19.59\%), B (25.28\%), C (22.7\%) and D (21.88\%). There were variations on other proximate compositions observed. The produced wine was not contaminated with bacteria and fungi. Sensory evaluation of the wine revealed acceptable aroma/flavor and taste. This study indicates that Saccharomyces cerevisiae strain from the palm wine have good fermentative performance which suggested that it could be used for fruit wine production and other industrial applications preceded by further experiments.
\end{abstract}

Keywords: Yeast, date palm fruit, fermentation, wine, proximate composition

\section{Introduction}

Over the decades, the definition of Wine as an alcoholic beverage derived from fermented grape juice has been attributed to other alcoholic beverage from fermented fruit and vegetable. Fermented beverages and alcoholic drink culturally and socially accepted product for consumption, drinking, entertainment, customary practices and religious purpose. It starts with harvesting grapes separation of juice before fermentation and concludes with the variety of storage and ageing steps (Willey et al., 2008). Apples berries and blackcurrant are sometime also fermented for wine production. Grape berries have a natural chemical balance which allow a completely fermentation without the addition of sugar, enzyme or other nutrient. It is a rich source of vitamins, many essential amino acid, minerals, fatty acid and others; however other fruits with same characteristics have been discovered and used effectively for wine production (Awe, 2011). Across the globe (Europe, America Australia, Asia and currently, Africa), wine making processes are popular (Balogu et al., 2016).

Honey is a sweets (mostly consisting of monosaccharide of fructose, glucose) jelly-like substance made from the nectar of flowers by bees. The high sugar content present in honey predisposes it as a good substance for yeast fermentation to produce alcohol and carbon dioxide gas. Different fermentation technologies have been applied to achieve a various degrees of alcoholic honey beverages, popularly known as mead (Kraus, 2017). Most processes undertake a minimum of 21 days fermentation to achieve $7.6 \%-22 \%$ alcoholic content (Gupta \& Sharma, 2009) compared to others fermented foods, alcoholic beverages of honey -fruits from mixture mostly have mostly been documented in personal blogs, as well as unpublished and scant published studies .There are studies of honey - 
fruit meads from mixture of honey with fruit and vegetable such as apple, banana, berry, soya, grape, etc. (Sarba, 2015).

Dates are the sweets fruits of the tree phonenix dactylifera or date palm. This fruit are being relish all over the world and virtually all age of group of people, primary as a source of energy. It is rich in minerals, specially potassium, calcium and iron, along with many antioxidants and flavonoids (Habib \& Ibrahim, 2011). It high dietary fibers, often makes it good food supplement for hyperglycemic patient (Vayalil, 2012). Beside these the dates are cholesterol free, fat free and sodium free. Very little knowledge is available on alcoholic beverages being produced from this fruit. The high sugar content of the fruit has been commercially exploited to produce vinegar directly. Date palm (Phoenix dactylifera), is a tropical and subtropical tree, belonging to the family Palmae (Arecaceae). It is one of mankind's oldest cultivated plants, and in the Arabian Peninsula it has played an important role in the day-to-day life of the people for the last 7000 years. Worldwide production, utilization and industrialization of dates are continuously increasing and as per the production of date fruits are on the increase as recorded for some of the major date producing countries like Egypt, Saudi Arabia, Iran, UAE and Algeria. Date fruit is marketed all over the world as a high value confectionery, and as a fresh fruit it remains an important subsistence crop in most of the desert areas. It is produced largely in the hot arid regions of the world particularly in Gulf Cooperation Council (GCC) countries, and Saudi Arabia is considered as one of the world's major producer of dates. The development of date fruits is divided into three stages, Khalal, Rutab and Tamr, and dates are generally harvested at the fully ripened Tamr stage, that is after the development of Total Soluble Solids (TSS) of 60-70 brix that are edible at this stage. Most dates are consumed at the Rutab (semi-ripe) and Tamr (fully-ripe) stages, with little or no processing. Huge amount of wastes are generated from the Kabkab date and the wastes have potential for use in date syrup production with economic advantages (Al-Hooti et al., 1997). The date palm is dioecious perennial, the females of which normally begin to bear date fruits after four years depending on the agronomic practices. It is a monocotyledonous plant with no tap roots but fibrous root system. The trunk is vertical and columnar of the same girth all the way up. The fruit is single, oblong one seeded berry with terminal stigma, a fresh pericarp and a membranous endocarp (Zaid \& Wet, 1999).

Unique strains Saccharomyces cerevisiae are involve in fermentation of most fruits and vegetables, with high alcohol content up to $20 \%$, and acceptable flavour and aroma (Jyoti \& Kasipathy, 2010). The aim of this study was to produce wine from fermentation of honey slurry and date palm fruit blend using Saccharomyces cerevisiae isolated from palm wine.

\section{Materials and Methods}

\subsection{Collection of Samples}

A total of $6 \mathrm{~kg}$ of freshly harvested honey was purchased from a honey bee farmer and date palm fruit was purchased from local market both in Kaduna, Nigeria. Honey and date palm fruit were transported in a clean plastic bottle $\left(<4^{\circ} \mathrm{C}\right)$ and plastic bag respectively to the microbiology laboratory of the Kaduna State University. Honey and date palm fruit was stored in refrigerator and at room temperature respectively, prior to preparation and fermentation for wine production.

\subsection{Isolation and Identification of Yeast from Palm Wine}

Sabouraud Dextrose (SDA) was prepared according to manufacture instruction and supplement with $50 \mathrm{mg} / \mathrm{m}$ chloramphenicol for selective enumeration of yeast. Serial dilution of the palm wine was carried out and was inoculated using pour plate techniques pure culture was made on yeast glucose agar plate. Microscopic examination of the isolate was carry out using wet mount method according to the description of Thais and Danilo (2002).

\subsection{Carbohydrates Utilization Test on Yeast Isolates from Palm Wine}

One (1) $\mathrm{ml}$ each of glucose, fructose, sucrose, lactose, mannose and maltose sugar were prepared using yeast fermentation broth (YFB) and dispensed $10 \mathrm{ml}$ volume into clean test tubes. Clean Durham tubes were introduced into the tubes, displaced all bubbles and then autoclave at $121^{\circ} \mathrm{C}$ for 15 minutes and allowed to cool. The sterile broth was inoculated with $0.2 \mathrm{ml}$ yeast culture broth and incubated at room temperature for 72 hours and observed evidence of fermentation. The ability to ferment six different carbohydrates was assessed by looking for the formation of gas $\left(\mathrm{CO}_{2}\right)$ in durham tube and color change of the fermentation media (Olowonibi, 2017).

\subsection{Percentage Ethanol Tolerance Test}

The test was carried out according to Alobo and Offonry (2009), where $2 \%, 5 \%, 8 \%, 11 \%, 14 \%, 16 \%$ and $19 \%$ of ethanol in molten yeast glucose agar medium were prepared and poured in sterile petri dishes. The plates were inoculated with the pure culture yeast isolates and incubated at room temperature for $72 \mathrm{hours}$. 


\subsection{Preparation and Fermentation of Honey Slurry and Date Palm Fruit Juice Blend}

Date palm fruit was slice using a sterile shape knife to remove seed and macerate using a clean sterile grinding engine, to produce a small, granular texture of the date palm fruit so has to increase the surface area of the for activity of fermentation. Juice was press out from the slurries sieve with muslin bags and was label as dates juice (DJ). Honey was dilute with water at the ratio of 1.1 and was label as slurry (HS).Four (4) set of $2000 \mathrm{ml}$ long necked round bottom glass flask were washed and label with the flowing code A (1.1) B (1.2) C (2.1) and control as CTRL (1:0). The ratios in parentheses denote the mixture of HS:DJ of each tagged flask to the maximum of $1800 \mathrm{~mL}$.This means that A was mixture of $900 \mathrm{mLHS}+900 \mathrm{~mL}$ DJ,B(600 mLHS+1200 mL DJ), C(1200mL HS+600 mL DJ) and CTRL(1800mlHS only).The glass flasks were sealed with airtight gas value and steam sterilized $\left(121^{\circ} \mathrm{C}\right.$ at pressure $15 \mathrm{psi}$ for 15 minute) and were allowed to cool at ambient temperature below $35^{\circ} \mathrm{C}$ before the addition of $200 \mathrm{~mL}$ of standardized starter culture $(\sim 6.0 \log 10 \mathrm{CFU} / \mathrm{mL})$ and vigorous agitation for 2 minutes. The setups was fermented for 21 days at room temperature $\left(25 \pm 2^{\circ} \mathrm{C}\right)$, periodically agitated, and degassed for 2-days intervals. The wine was pasteurized $\left(60^{\circ} \mathrm{C}\right)$ for 15 minutes to stop fermentation. Clarified wine (by siphoning supernatant of wine sediment into a clean bottle) were stored in $100 \mathrm{ml}$ glass vessels seeded with $5 \mathrm{~mL}$ of citric acid $(0.02 \mathrm{w} /)$ solution to limit bacterial growth as described by Balogu and Towobola (2017).

\subsection{Specific Gravity of the Produced Wine}

Specific gravity (SG) of the produced wine was determined by measuring $50 \mathrm{ml}$ of the wine sample into a measuring cylinder at $20^{\circ} \mathrm{C}$, and a hydrometer was drop into it to determine the specific gravity with appropriate temperature corrector factor (Balogu \& Towobola, 2017).

\subsection{Proximate Composition and Physiochemical Analysis of the Produce Honey and Date Palm Fruit Juice Wine}

Nutritional proximate composition of HS and DF mixtures was analyze with Association of Office Analytical Chemist (AOAC) method and Selected parameters (titratable acidity $\mathrm{pH}$, and temperature ) was detected using the method of Association of Official Analytical Chemist (AOAC) method with slight modification as describe by Balogu et al. (2016). Ambient temperature and $\mathrm{pH}$ was determined with a dual $\mathrm{pH}$ and temperature portable digital device (Jenway 3510, Camlab, UK). Probes of $\mathrm{pH}$ and temperature was dipped into 50ml sample for (2minute for stable reading). Recorded data was means of triplicate values. Total titratable acidity (TTA) was assessed by titrating $10 \mathrm{~mL}$ of sample with $0.1 \mathrm{M}$ of $\mathrm{NaOH}$ to obtain 7.1 natural $\mathrm{pH}$. The titre of $\mathrm{NaOH}$ was used to calculate the TTS $(7.5 \times 0.1 \times$ titer value) and was expressed in $\mathrm{g} / \mathrm{L}$; acetic acid and using OIV (International Organization of Vine and Wine) methods. Free $\mathrm{SO}_{2}$ was calculated (Coelho et al., 2015).

\subsection{Determination of Ash Content}

This was carry out as describe by Moronkola et al. (2011). Where porcelain crucible with lid was ignite in a hot Bunsen burner flame and was transfered into desiccators to cool and the crucible was weighed $.5 \mathrm{~g}$ of the sample was accurately weigh into the crucible and was gently place in the muffle furnace set at $600^{\circ} \mathrm{C}$ for 4 hours. The crucible was place in desiccators to cool. The ash sample in the crucible was kept at room temperature in sterile laminar flow until for fermentation up to 5 days (Butz, 2007). The total ash content was calculated by using this formula: Total Ash content $(\%$ of ash $)=($ weight of ash $/$ weight of sample $) \times 100$

\subsection{Determination of Total Carbohydrate Content}

Chemical analysis for the determination of total carbohydrate was checked by the phenol-sulphuric acid method (Moronkola et al., 2011).

\subsection{Total Protein Analysis}

The total protein analysis was carried out by Biuret method.

\subsection{Determination of Fat Content}

Homogenized date- honey $(10 \mathrm{~g})$ was progressively added to a small amount of a chloroform /methanol 2:1(v/v) mixture (up to $200 \mathrm{ml}$ ), with vigorous shaking, and then the extraction was carry out on for a further 2 hours, with constant stirring. This was filtered and the residue was re-washed with fresh solvent and press. Fifty milliliters of $0.88 \%$ potassium chloride was add to the filter with content stirring. The aqueous layer (upper) was removed by aspiring and the procedure repeated a couple of times. This was dry by pressing through anhydrous sodium sulfate, and then solvent was remove by using a rotary evaporator. The residue was weigh to find the fat content (Moronkola et al., 2011).

\subsection{Determination of Moisture Content}

Exactly $5 \mathrm{~g}$ of the sample was weighed into a petri dish and was placed in air draught oven at $100^{\circ} \mathrm{C}$ for 1 hour. The Petri dish will then be weigh after cooling. The process was repeated thrice until a constant weigh is obtained. Loss in weigh was calculated as the percentage moisture content (Moronkola et al., 2011). 


\subsection{Microbial Analysis of Honey and Date Palm Fruit Juice Blend Wine}

Microbial population of wine was evaluated using PDA (yeast), Nutrient Agar (bacteria), and relevant biochemical assays, in accordance with the method ISO (International Standard Organization). Four periodic microbial sampling was done at 15-day interval to determine the microbial kinetic profile of the system (Balogu \& Towobola, 2017).

\subsection{Sensory Evaluation of the Produced Honey and Dates Palm Fruit Juice Blend Wine}

A total number of 20 assessors (Train and Untrained) from staff and student of Kaduna State University was selected to evaluate the wine using a 7 - point hedonic scale. Only +18 years old assessor (those with prior exposure and non exposure to alcoholic beverages) was selected to limit biased responds. Prior to sensory evaluation, ISO standard for selection, training (Less than - 2days) and monitoring of assessor (ISO8886:2012), design of testing room (ISO8589:2010), and methodology of monitoring performance of sensory panel (ISO11132:2009) followed. Each assessor was served with $50 \mathrm{ml}$ of test sample $\left(182^{\circ} \mathrm{C}\right)$ with $250 \mathrm{ml}$ wine testing glasses (ISO3591: 1977); result was ranked (ISO8587:2006) and was express in according with the sensory vocabulary (ISO5492: 2008en) (Balogu \& Towobola, 2017).

\subsection{Statistical Analysis of Data}

All data generated from this study was subjected to relevant statistical tools (ANOVA, Chi-square, and Duncans Multiple Range Test) using SAS statistical software (Version 8, SAS institute, cary, NC, USA) and SPSS software (version 20 of 2014), and significance was taken at $95 \%$ confidence level.

\section{Results}

The morphology of the vegetative cells of the yeast isolates were observed. Culturally, the yeast isolates had flat elevation and were creamy in appearance and were circular in shape (Table1). Saccharomyces cerevisiae showed variation of utilization of six different sugars. The palm wine strain of Saccharomyces cerevisiae utilized glucose, maltose and sucrose but failed to grow on fructose, lactose and mannitol after 48 hours (Table 2). The S. cerevisiae were tolerant to $2,5,8,11$ and $14 \%$ alcohol and not tolerance to 16 and $18 \%$ alcohol (Table 3). The result obtained from proximate composition of honey slurry and dates palm fruit juice blend before fermentation and production of wine are presented in table 4 . Sample A with equal proportion of honey and dates palm fruit juice $(500 \mathrm{ml}$ honey and $500 \mathrm{ml}$ dates palm fruit juice) had a moisture content, ash content, crude fat, protein content and carbohydrate of $79.20 \%, 0.12 \%, 0.07 \%, 1.02 \%$, and $19.59 \%$ respectively while the specific gravity was 1.0110 . The proximate composition of sample B with $250 \mathrm{ml}$ honey and $750 \mathrm{ml}$ dates palm fruit juice revealed moisture content of $73.42 \%$ and ash content, protein content, crude fat and total carbohydrate of $0.17 \%, 1.04 \%, 0.09 \%$, and $25.28 \%$ while the specific gravity was 1.0003 .The proximate composition sample $\mathrm{C}$ with $750 \mathrm{ml}$ honey and 250 dates palm fruit juice revealed moisture content of $76.06 \%$ and ash content, protein content, crude fat and total carbohydrate of $0.15 \%$, $1.03 \%, 0.06 \%$ and $22.7 \%$ while the specific gravity was 1.0001 . The proximate composition of sample D with $1000 \mathrm{ml}$ of honey and $0 \mathrm{ml}$ of dates palm fruit juice revealed moisture and ash content of $78.03 \%$ and $0.09 \%$ respectively while protein content and crude fat were not detected (ND) and the total carbohydrate was $21.88 \%$ and specific gravity was 1.1010 (Table 4). The result obtained from proximate composition of honey slurry and dates palm fruit blend wine are showed in table 5. The result revealed that after fermentation and production of wine, sample A with equal proportion of honey and dates palm fruit extract $(500 \mathrm{ml}$ honey and $500 \mathrm{ml}$ dates palm fruit juice) had a moisture content of $90.01 \%$, ash content of $0.09 \%$, crude fat of $0.002 \%$, the protein content of $1.04 \%$, carbohydrate $(8.84 \%$ ) and specific gravity of 1.0110 . The proximate composition of sample B with $250 \mathrm{ml}$ honey and $750 \mathrm{ml}$ dates palm fruit juice revealed moisture content of $88.60 \%$, ash content of $0.010 \%$, protein content of $1.05 \%$, crude fat of $0.01 \%$, total carbohydrate of $10.2 \%$ and specific gravity of 1.0003 . The proximate composition of sample $\mathrm{C}$ with $750 \mathrm{ml}$ honey and 250 dates palm fruit juice revealed moisture content of $89.20 \%$, the ash content of $0.08 \%$, protein content of $1.00 \%$, total carbohydrate was $9.72 \%$ while crude fat was not detected (ND) and specific gravity was 1.0001 .The proximate composition of sample $\mathrm{D}$ with $1000 \mathrm{ml}$ of honey and $0 \mathrm{ml}$ of dates palm fruit juice revealed moisture content $86.05 \%$, the ash content was $0.07 \%$, protein content, total carbohydrate of $13.88 \%$ while crude fat were not detected (ND) and specific gravity of 1.1010 was recorded (Table 5). The result of the physicochemical composition of sample A with equal amount of honey slurry and dates palm fruit juice $(500 \mathrm{~mL}-500 \mathrm{~mL})$ revealed initial $\mathrm{pH}$ of 4.3 , temperature of $29^{\circ} \mathrm{C}$, gravity of 1.122 while final the $\mathrm{pH}$ was 5.4 , temperature was $26^{\circ} \mathrm{C}$ and specific gravity was 1.0110. The $\mathrm{pH}$ after dealcoholization was 5.3, temperature was $25^{\circ} \mathrm{C}$, TTA was 9.5 and TTA after dealcoholization was 7.9. Sample B with $250 \mathrm{~mL}$ of honey slurry and $750 \mathrm{ml}$ of dates palm fruit juice revealed the initial $\mathrm{pH}$ of 4.4 , temperature of $28^{\circ} \mathrm{C}$, specific gravity of 1.119 while final $\mathrm{pH}$ was 5.4 , temperature was $26^{\circ} \mathrm{C}$ and specific gravity was 1.0003 . The $\mathrm{pH}$ after dealcoholization was 5.4 , temperature was $24^{\circ} \mathrm{C}$, TTA before dealcoholization was 5.6 and TTA after dealcoholization was 6.4 . Sample $\mathrm{C}$ with $750 \mathrm{~mL}$ of honey slurry and $250 \mathrm{~mL}$ dates palm fruit juice blend 
revealed initial $\mathrm{pH}$ of 6.5 , temperature of $28^{\circ} \mathrm{C}$, specific gravity of 1.120 while final $\mathrm{pH}$, temperature and specific gravity were $5.4,26^{\circ} \mathrm{C}$ and 1.0001 respectively. The $\mathrm{pH}$ and temperature after dealcoholization were 5.5 and $24^{\circ} \mathrm{C}$ respectively while the TTA before and dealcoholization were 7.4 and 8.8 . Sample D with $1000 \mathrm{ml}$ of honey slurry and $0 \mathrm{ml}$ of dates palm fruit juice revealed initial $\mathrm{pH}$ and temperature 4.3 and $29^{\circ} \mathrm{C}$ while the initial specific gravity was 1.3125 . The final $\mathrm{pH}$, temperature and specific gravity were $5.4,26^{\circ} \mathrm{C}$, and 1.1010 respectively while $\mathrm{pH}$, temperature after dealcoholization were 5.3 and $24^{\circ} \mathrm{C}$ while TTA before dealcoholization was 6.7 (Table 6). The produced wine was free of bacteria and fungi contaminations (Table 7a \&b). The sensory evaluation of sample A were significantly different $(p<0.05)$, the overall acceptability was within the range of $2-4$ in the hedonic scale, while sample B was not significantly different $(\mathrm{p}>0.05)$. The range of the overall acceptability is within $2-5$ in the hedonic scale and sample $\mathrm{D}$ is significantly different $(\mathrm{p}<0.05)$, the overall acceptability was within the range of 3-9. Among the accessed wines, sample $\mathrm{C}$ and $\mathrm{D}$ had more acceptability probably due to the sweet taste and aroma (Table 8,9 , 10 and 11).

Table 1. Cultural and Morphological Characteristics of Yeast Isolates from Palm Wine

\begin{tabular}{cc}
\hline Parameters & Result \\
\hline Shape & Circular \\
Elevation & Flat \\
Pigmentation & Creamy \\
Budding & Positive \\
\hline
\end{tabular}

Table 2. Carbohydrate Fermentation Characteristics of Yeast Isolates from Palm Wine

+: positive, -: negative.

\begin{tabular}{lc}
\hline Sugars & Result \\
\hline Fructose & - \\
Glucose & + \\
Lactose & - \\
Maltose & + \\
Mannose & - \\
Sucrose & + \\
\hline
\end{tabular}

Table 3. Alcohol Tolerance Test against Yeast Isolates from Palm wine

\begin{tabular}{lccccccc}
\hline Fermentation isolates & \multicolumn{8}{c}{ Ethanol Concentration (\%) } \\
\hline & 2 & 5 & 8 & 11 & 14 & 16 & 19 \\
1 & ++ & ++ & ++ & ++ & ++ & - & - \\
2 & ++ & ++ & ++ & ++ & ++ & - & - \\
\hline
\end{tabular}

++: positive growth/ tolerance, -: no growth, \%: percentage.

Table 4. Proximate Composition of Honey Slurry-Dates Palm fruit Juice Blend

\begin{tabular}{lrrrr}
\hline \multirow{2}{*}{ Parameters } & \multicolumn{4}{c}{ Samples } \\
\cline { 2 - 5 } & A 1:1 & B 1:2 & C 2:1 & D 1:0 \\
\hline Moisture content (\%) & 79.20 & 73.40 & 76.06 & 78.03 \\
Ash content (\%) & 0.12 & 0.17 & 0.15 & 0.09 \\
Protein (\%) & 1.02 & 1.04 & 1.03 & ND \\
Crude fat (\%) & 0.07 & 0.09 & 0.06 & ND \\
Total carbohydrate (\%) & 19.59 & 25.28 & 22.7 & 21.88 \\
Specific gravity & 1.122 & 1.199 & 1.120 & 1.3125 \\
\hline
\end{tabular}

Key: A $(1: 1)=$ honey $(500 \mathrm{~mL})+$ dates palm fruit extract $(500 \mathrm{~mL})$, B $(1: 2)=$ honey $(250 \mathrm{~mL})+$ dates palm fruit extract $(750 \mathrm{~mL}), \mathrm{C}(2: 1)=$ honey $(750 \mathrm{~mL})+$ dates Palm fruit $(250 \mathrm{~mL}$ CTRL $(1: 0)=$ honey $(1000 \mathrm{~mL})+$ dates palm fruit extract $(0 \mathrm{~mL})$.

Key: $\mathrm{ND}=$ not detected 
Table 5. Proximate Composition of Honey Slurry-Dates Palm fruit Juice Blend Wine

\begin{tabular}{lrrrr}
\hline \multirow{2}{*}{ Parameters } & \multicolumn{4}{c}{ Wine Sample } \\
\cline { 2 - 5 } & A 1:1 & B 1:2 & C 2:1 & D 1:0 \\
\hline Moisture content (\%) & 90.01 & 88.60 & 89.20 & 86.05 \\
Ash content (\%) & 0.09 & 0.010 & 0.08 & 0.07 \\
Protein (\%) & 1.04 & 1.05 & 1.00 & ND \\
Crude fat (\%) & 0.002 & 0.01 & ND & ND \\
Total carbohydrate (\%) & 8.84 & 10.24 & 9.72 & 13.88 \\
\hline
\end{tabular}

Key: A $(1: 1)=$ honey $(500 \mathrm{~mL})+$ dates palm fruit extract $(500 \mathrm{~mL}), \mathrm{B}(1: 2)=$ honey $(250 \mathrm{~mL})+$ dates palm fruit extract $(750 \mathrm{~mL}), \mathrm{C}(2: 1)=$ honey $(750 \mathrm{~mL})+$ dates Palm fruit $(250 \mathrm{~mL}$ CTRL $(1: 0)=$ honey $(1000 \mathrm{~mL})+$ dates palm fruit extract $(0 \mathrm{~mL})$.

Key: $\mathrm{ND}=$ not detected.

Table 6. Physicochemical Composition of Honey Slurry and Dates Palm Fruit Juice Blend

\begin{tabular}{lllll}
\hline \multirow{2}{*}{ Parameters } & \multicolumn{4}{c}{ Wine Sample } \\
& $\mathrm{A}(1: 1)$ & $\mathrm{B}(1: 2)$ & $\mathrm{C}(2: 1)$ & $\mathrm{D}(1: 0)$ \\
\hline Initial pH & 4.3 & 4.4 & 4.4 & 4.3 \\
Initial Temperature & 29 & 28 & 28 & 29 \\
Initial Specific Gravity & 1.122 & 1.119 & 1.120 & 1.3125 \\
Final pH & 5.3 & 5.4 & 5.5 & 5.3 \\
final Temperature & 25 & 24 & 24 & 24 \\
Final Specific Gravity & 1.0110 & 1.0003 & 1.0001 & 1.1010 \\
pH after Dealcoholization & 5.4 & 5.4 & 5.4 & 5.4 \\
Temperature after Dealcoholization & 24 & 24 & 24 & 24 \\
TTA before Dealcoholization & 9.5 & 5.6 & 7.4 & 6.7 \\
TTA after Dealcoholization & 7.9 & 6.4 & 8.8 & 5.2 \\
\hline
\end{tabular}

Key: A $(1: 1)=$ honey $(500 \mathrm{~mL})+$ dates palm fruit extract $(500 \mathrm{~mL})$, B $(1: 2)=$ honey $(250 \mathrm{~mL})+$ dates palm fruit extract $(6 \mathrm{~mL}, \mathrm{C}(2: 1)=$ honey $(750 \mathrm{~mL})+$ dates Palm fruit $(250 \mathrm{~mL}$ CTRL $(1: 0)=$ honey $(1000 \mathrm{~mL})+$ dates palm fruit extract $(0 \mathrm{~mL})$. Key TTA; Total Titratable Acidity

Table 7a. Bacteriological Quality Assessment of the produced Wine

\begin{tabular}{lllll}
\hline \multicolumn{5}{c}{ Wine Sample (CFU/mL) } \\
\hline Treatment & $\mathrm{A}(1: 1)$ & $\mathrm{B}(1: 2)$ & $\mathrm{C}(2: 1)$ & $\mathrm{D}(1: 0)$ \\
Before pasteurization & $1.48 \times 10^{4}$ & $1.57 \times 10^{4}$ & $1.52 \times 10^{4}$ & $1.56 \times 10^{4}$ \\
After pasteurization & 0 & 0 & 0 & 0 \\
\hline
\end{tabular}

Table 7b. Mycological Quality Assessment of the Produced Wine

\begin{tabular}{lllll}
\hline & \multicolumn{4}{c}{ Samples } \\
\cline { 2 - 5 } & $\mathrm{A}(1: 1)$ & $\mathrm{B}(1: 3)$ & $\mathrm{C}(3: 1)$ & $\mathrm{D}(1: 0)$ \\
\hline Before pasteurization & $5.0 \times 106$ & $4.4 \times 106$ & $4.0 \times 106$ & $5.4 \times 106$ \\
After pasteurization & 0 & 0 & 0 & 0 \\
\hline
\end{tabular}

Key

\section{$\mathrm{CFU} / \mathrm{mL}=$ Colony Forming Unit}

ND: Not Detected, Sample A honey slurry and date fruit juice $(1: 1)=500 \mathrm{~mL}: 500 \mathrm{~mL}$, Sample B honey slurry and date fruit juice $(1: 3)=250 \mathrm{~mL}: 750 \mathrm{~mL}$, Sample C honey slurry and date fruit juice $(3: 1)=750 \mathrm{~mL}: 250 \mathrm{~mL}$, Sample D honey slurry and date fruit juice $(1: 0)=1000 \mathrm{~mL}$ 
Table 8. Sensory Evaluation of wine (A-1:1)

\begin{tabular}{lccccccccc}
\hline \multirow{2}{*}{ Parameters } & \multicolumn{10}{c}{ Hedonic scale } \\
\cline { 2 - 11 } & 1 & 2 & 3 & 4 & 5 & 6 & 7 & 8 & 9 \\
\hline Appearance & 0 & 0 & 0 & 6 & 5 & 4 & 3 & 0 & 2 \\
Texture & 0 & 0 & 0 & 4 & 6 & 5 & 3 & 1 & 1 \\
Aroma & 0 & 0 & 4 & 3 & 3 & 4 & 2 & 3 & 1 \\
Sweet & 4 & 0 & 0 & 1 & 0 & 4 & 2 & 1 & 1 \\
Sour & 0 & 1 & 0 & 2 & 1 & 1 & 0 & 1 & 0 \\
Bitter & 0 & 0 & 0 & 1 & 0 & 0 & 0 & 0 & 0 \\
Overall acceptability & 0 & 2 & 2 & 2 & 2 & 4 & 4 & 2 & 2 \\
\hline
\end{tabular}

Hedonic scale.

9=like extremely, $8=$ like very much, $7=$ like moderately, $6=$ like slightly, $5=$ neither like nor dislike $4=$ like slightly, $3=$ dislike moderately, $2=$ dislike very much, $1=$ dislike slightly.

Table 9. Sensory Evaluation of Wine (B 2:1)

\begin{tabular}{lcccccccccc}
\hline \multirow{2}{*}{ Parameters } & \multicolumn{10}{c}{ Hedonic scale } \\
\cline { 2 - 12 } & 1 & 2 & 3 & 4 & 5 & 6 & 7 & 8 & 9 & \\
\hline Appearance & 0 & 0 & 0 & 2 & 3 & 5 & 5 & 5 & 0 & 0 \\
Texture & 0 & 0 & 0 & 3 & 3 & 4 & 6 & 4 & 0 & 0 \\
Aroma & 0 & 0 & 1 & 1 & 4 & 5 & 4 & 5 & 0 & 0 \\
Sweet & 0 & 2 & 1 & 0 & 1 & 2 & 0 & 0 & 0 & 0 \\
Sour & 0 & 7 & 3 & 2 & 0 & 0 & 0 & 0 & 0 & 0 \\
Bitter & 0 & 4 & 0 & 0 & 0 & 0 & 0 & 0 & 0 & 0 \\
Overall acceptability & 0 & 2 & 2 & 0 & 5 & 3 & 3 & 2 & 3 & 0 \\
\hline
\end{tabular}

Hedonic scale

$9=$ like extremely, $8=$ like very much, $7=$ like moderately, $6=$ like slightly, $5=$ neither like nor dislike $4=$ like slightly, $3=$ dislike moderately, $2=$ dislike very much, $1=$ dislike slightly

Table 10. Sensory Evaluation of Wine (C 1:2)

\begin{tabular}{lccccccccc}
\hline \multirow{2}{*}{ Parameters } & \multicolumn{10}{c}{ Hedonic scale } \\
\cline { 2 - 10 } & 1 & 2 & 3 & 4 & 5 & 6 & 7 & 8 & 9 \\
\hline Appearance & 0 & 0 & 0 & 3 & 0 & 6 & 6 & 5 & 1 \\
Texture & 0 & 0 & 0 & 5 & 0 & 5 & 9 & 1 & 1 \\
Aroma & 0 & 0 & 0 & 0 & 6 & 4 & 5 & 2 & 3 \\
Sweet & 0 & 0 & 0 & 1 & 3 & 2 & 5 & 0 & 0 \\
Sour & 1 & 0 & 0 & 1 & 1 & 1 & 1 & 2 & 0 \\
Bitter & 1 & 0 & 1 & 0 & 0 & 0 & 1 & 1 & 0 \\
Overall acceptability & 0 & 0 & 0 & 5 & 1 & 0 & 6 & 5 & 3 \\
\hline
\end{tabular}

Hedonic scale

$9=$ like extremely, $8=$ like very much, $7=$ like moderately, $6=$ like slightly, $5=$ neither like nor dislike $4=$ like slightly, $3=$ dislike moderately, $2=$ dislike very much, $1=$ dislike slightly 
Table 11. Sensory Evaluation of Wine (D 1:0)

\begin{tabular}{lccccccccc}
\hline \multirow{2}{*}{ Parameters D } & \multicolumn{10}{c}{ Hedonic scale } \\
\cline { 2 - 10 } & 1 & 2 & 3 & 4 & 5 & 6 & 7 & 8 & 9 \\
\hline Appearance & 0 & 0 & 0 & 0 & 2 & 3 & 5 & 7 & 3 \\
Texture & 0 & 0 & 3 & 0 & 0 & 2 & 7 & 6 & 3 \\
Aroma & 0 & 0 & 0 & 1 & 1 & 3 & 7 & 4 & 4 \\
Sweet & 0 & 0 & 0 & 1 & 1 & 3 & 3 & 5 & 4 \\
Sour & 1 & 0 & 1 & 0 & 1 & 1 & 1 & 1 & 0 \\
Bitter & 0 & 0 & 0 & 0 & 0 & 0 & 0 & 0 & 0 \\
Overall acceptability & 0 & 0 & 0 & 0 & 2 & 3 & 6 & 5 & 4 \\
\hline
\end{tabular}

Hedonic scale

$9=$ like extremely, $8=$ like very much, $7=$ like moderately, $6=$ like slightly, $5=$ neither like nor dislike $4=$ like slightly, $3=$ dislike moderately, $2=$ dislike very much, $1=$ dislike slightly

\section{Discussion}

Culturally, the yeast isolates had flat elevation and creamy in appearance and was circular in shape. The yeast showed variation of utilization of the six different sugars. This could be attributed to the metabolic activities of the yeast during fermentation. The yeast had variations on the alcohol tolerance (between 2 and $14 \%$ ). The organism was probably identified as Saccharomyces cerevisiae. Similarly, Ukwuru \& Awah (2013) reported that purified yeasts from palm wine showed highly viable cells and good metabolic activity during substrate fermentation. The proximate composition of various mixtures (blend) before fermentation revealed high percentage moisture content of A (79.20\%), B (73.42\%), C (76.06) and D (78.03) and this could be as a result of the ratio of honey slurry and date palm fruit juice blend. This according to Okaka (2010) accounts for their high perishable nature and their short shelf life under normal storage condition. The pre-proximate of the blend wine in this study is similar to the study of Yabaya et al. (2016) on the production of wine from fermentation of Vitis vinifera (grape) juice using $S$. cerevisiae strain isolated from palm wine. Though revealing high percentage moisture content $(82.43 \%)$ due to the nature of fruit used, the fruit also contained reasonable amount of total carbohydrate (14.23\%) which invariably account for their high caloric values suggesting the presence energy source for metabolic activity of the yeast, the fruit also contain a protein content of $0.53 \%$ similar to the low protein content of $4.30 \%$. The moisture contents were significantly different $(\mathrm{p}<0.05)$. Chilaka et al. (2010) reported that the moisture content of wine do not have any remarkable relationship to the mixing ratios of the various wine blend. The produced wine contained reasonable amount of total carbohydrate A (19.59\%), B (25.28\%), C (22.7\%) and D (21.88\%) invariably account for their high caloric values suggesting the presence energy source for metabolic activity of the yeast. The carbohydrate content were significantly different $(\mathrm{p}<0.05)$. The protein content for sample A was $(1.02 \%)$, B (1.04\%), C (1.03\%) and D was not detected (ND) and according to Okegbile and Taiwo (2009), the low protein and mineral contents of the fruit as reported in this study is a probable indication that fear of over accumulation due to consumption of the fruits do not arise. The proximate composition in this investigation was in agreement with the general case for fruits as reported by Pearson (2007). The protein content were not significantly difference $(.>0.05)$. The results of the proximate composition after fermentation revealed high percentage moisture content for sample A as (90.01\%), B (88.60\%), C (89.20\%) and D (86.05\%) and this according to Okaka (2010) accounts for their high perishable nature and their short shelf life under normal storage condition the moisture content increase after fermentation. The moisture contents were significantly different $(\mathrm{p}<0.05)$ and do not have any remarkable relationship to the mixing ratios of the various wine blend as reported by Chilaka et al. (2010). The result also contained reasonable amount of total carbohydrate A ( 8.84\%), B (10.24\%), C (9.72\%) and D (13.88\%) invariably account for their high caloric values suggesting the presence energy source for metabolic activity of the yeast. the carbohydrates content reduced after fermentation. The carbohydrate content were significantly different $(\mathrm{p}<0.05)$. The protein content was A $(1.04 \%),(1.05 \%),(1.00 \%)$ and D (ND) and according to Okegbabile \& Taiwo (2009), the low protein and mineral contents of the fruit as reported in this study is a probable indication that fear of over accumulation due to consumption of the fruits do not arise. The proximate composition in this investigation was in agreement with the general case for fruits as reported by Pearson (2007) that the protein content were not significantly difference (.>0.05). The crude fat for sample A (0.07), B (0.09), C (0.06) and D (ND) were not significantly different $(>0.05)$. The ash content for sample A was $(0.12), \mathrm{B}(0.17), \mathrm{C}(0.15)$ and D $(0.09)$ and were not significantly difference $(>0.05)$. Ash content revealed that sample A was $(0.12), \mathrm{B}(0.17) \mathrm{C}$ $(0.15)$ and $\mathrm{D}(0.09)$, and were not significantly different $(>0.05)$. The present study revealed that $\mathrm{pH}$ values were 
within the range of 4.3- 5.4 of honey slurry and date palm fruit in the wine fermentation period. The $\mathrm{pH}$ is significantly difference $(\mathrm{p}<0.05)$. The trend of the changes in $\mathrm{pH}$ revealed consistent increases acidity of the fruit wine during the fermentation this could be due to the metabolic activities of the yeast. Chilaka et al. (2010) also recorded a similar $\mathrm{pH}$ ranged of 3.0 to 4.8 during fermentation of passion fruit, water melon and pineapple fruits must using commercial Saccharomyces cerevisiae. Studies have shown that during fermentation of fruits, low $\mathrm{pH}$ is inhibitory to the growth of spoilage organisms but creates conducive and competitive advantage environment for the growth of desirable organisms as reported by Reddy \& Reddy (2009). The temperature of honey slurry and dates palm fruit juice was within the range of $24-29^{\circ} \mathrm{C}$ and were not significantly different $(p>0.05)$ this could be attributed to the metabolic activities of the yeast during fermentation. The titrable acidity of honey slurry and dates palm fruit juice wine were significantly different $(\mathrm{p}>0.05)$. Only temperature $\left(27-29^{\circ} \mathrm{C}\right)$ and $\mathrm{pH}(4.4-5.4)$ were relatively stable among the assessed wines. Similar to this study, most previous studies on fruit and vegetable wines reported acidic beverages of $\mathrm{pH}$ below 6.0. Bacteria and fungi contamination of the wines were not observed probably due to pasteurization of the wines and hygienic nature in which the wines were produced. This is similar to the report of Balogu \& Towobola (2017). The sensory evaluation of sample A were significantly different ( $\mathrm{p}<$ $0.05)$, the overall acceptability is within the range of 2-4 in the hedonic scale, sample B was not significantly different ( $p>0.05$ ), the range of the overall acceptability is within $2-5$ in the hedonic scale. This could be attributed to the ratio of the honey slurry and dates palm fruit juice blend or fermentative ability of the yeast used. Sample D was significantly different $(\mathrm{p}<0.05)$. This is similar to the report of Balogu \& Towobola (2017) who worked on production of wine from honey slurry and coconut milk.

\section{Conclusion}

The yeast isolate was identified as Saccharomyces cerevisiae. The wine was produced using the palm wine Saccharomyces cerevisiae. High percentage alcohol was produced by the $S$. cerevisiae strain during fermentation of honey slurry and date palm fruit juice wine and the $\mathrm{pH}$ level of the wine fall within acceptable limits. The proximate composition of the wine revealed variations in the parameters analyzed. After pasteurization, the wines were free of microbes. The sensory evaluation indicates that the wines produced had general acceptability. This study therefore indicates that Saccharomyces cerevisiae strain isolated from the locally tapped palm wine can be used to make wine from honey slurry and date palm fruit.

\section{Recommendations}

1) More research is needed to refine the quality of wine for commercial production. The results also indicate that other fruit might have the potential to produce high quality wine of viability. This research needs to be extended to other fruit and vegetables.

2) Process optimization and scale up will be required; and hence starter culture obtain to augment the more expensive and non-available commercial wine Saccharomyces cerevisiae strain for better applications in the industries.

\section{Conflict of Interest}

The authors declare no conflict of interest.

\section{Acknowledgements}

The authors acknowledged the efforts and assistance of the technologists and the Department of Microbiology, Faculty of Science of the Kaduna State University for making the laboratory facilities available for this research.

\section{References}

Al-Hooti, S., Sidhu, J. S., \& Qabazard, H. (1997). Physicochemical characteristics of five date fruit cultivars grown in the United Arab Emirates. Plant Foods Human Nutrition., 50, 101-113.

Alobo, A. P., \& Offonry, S. U. (2009). Characteristics of coloured wine produced from roselle (Hibiscus sabdariffa) calyx extract. Journal of Institute Brewing, 3, 91-94.

Awe, S., \& Nnadoze S. N. (2015). Production and microbiological Assessment of Date palm fruit and pawpaw (Phoenix dactylifera L.) Fruit Wine. British Microbiology Research Journal, 8(3), 480-488.

Balogu, T. V., \& Towobola, O. (2017). Production and Quality Analysis of Wine from Honey and Coconut Milk Blend Using Saccharomyces cerevisiae. Fermentation, 3(2), 16.

Balogu, T. V., Abdulkadir, A., Ikegwu, M. T., Akpadolu, B., \& Akpadolu, K. (2016). Production and Sensory Evaluation of Non-Alcoholic Wine from Sugarcane and Tiger Nut Blend Using Saccharomyces cerevisiae. International Journal of Biosciences, Agriculture and Technology, 7(2), 7. 
Chilaka, C. A., Uchechukwu, N., Obidiegwu, J. E., \& Akpor, O. B. (2010). Evaluation of the efficiency of yeast isolates from palm wine in diverse fruit wine production. African Journal of Food Science, 4(12), 764-774.

Coelho, J. M., Howe, P. A., \& Sacks, G. L. (2015). A headspace gas detection tube method to measure SO2 in wine without disrupting SO2 equilibria. American Journal of Enology and Viticulture, 66(3), 257-265.

Gaupta, J. K., \& Sharma, R. (2009). Production Technology and quality characteristics of mead and fruit-honey wines. National Production Radiance, 8, 345-355.

Habib, H. M., \& Ibrahim, W. H. (2011). Nutritional quality of 18 date fruit varieties. International journal of food sciences and nutrition, 62(5), 544-551.

International Standard Organization (ISO). (2017). Sensory Analysis Standards. 2017. Retrieved March 11, 2018, from https://www.iso.org

Jyoti, P. T., \& Kasipachy, K. (2010). Fermented Food and Beverages of the world. London: CRC Press.

Kraus, E. C. (2012). Mead (Honey) Wine. Copyright of Home Wine \& Beer Making Supplies. Retrieved from www.eckraus.com

Moronkola, B. A., Olawu, R. A., Tovide, O. O., \& Ayejuyo, O. O. (2011). Determination of proximate and mineral contents. Science Reve Chemical Commum, 1(1), 1-6.

Okaka, J. C. (2010). Tropical Plant Perishable Processing, Storage and handling. New Heaven, 55-60.

Okegbile, E. O., \& Taiwo, E. A. (2009). The Nutritional potential of black velvet. Nigerian Journal of Nutrition Science, 115-121.

Olowonibi, O. O. (2017). Isolation and Characterization of Journal of Palm Wine Strains of Saccharomyces cerevisiae Potentially used as Bakery Yeast. European Experimental Biology, 7, 11.

Pearson, D. (2007). The Chemical Analysis of Foods. Churchill Living, 56-89.

Reddy, L. V., \& Reddy, O. V. (2009). Production and optimization and characterization of wine from mango. Natural Product Journal, 426-435.

Sarba, A. C. (2015). Obtaining Different Types of Wine Products from Honey. Ph.D. Thesis, Doctoral School of Engineering, Faculty of Animal Breeding and Biotechnologies, University of Agricultural Science and Veterinary Medicine, Cluj-Napoca, Romania, 2015. Retrieved March 11, 2018, from http://www.usamvcluj.ro/en/files/ teze/en/2015/sarba.pdf

Thais, M. G., \& Danilo, G. M. (2006). Isolation and Characterization of Saccharomyces cerevisiae strains. Brazilian Journal of Pharmaceutical Sciences, 4-6.

Ukwuru, M. U., \& Awah J. I. (2013). Properties of palm wine yeasts and its performance in wine making. African Journal of Biotechnology, 12(19), 2670-2677.

Vayalil, P. K. (2012). Dates Fruit (phenix dactylifera Linn): An Emerging Medicinal Food. Critical Reviews in Food and Nutrition, 52(3), 249-271.

Willey, J. M., Sherwood, L. M., \& Woolverton, C. J. (2008). Prescott, Harley and Kleins's Microbiology (7th Ed.). New York: McGraw-Hill Higher Education.

Yabaya, A., Bobai, M., \&Adebayo, L. R. (2016). Production of Wine from Fermentation of Vitis vinifera (Grape) Juice using Saccharomyces cerevisie Strain Isolated from Palm Wine. International Journal of information Research and Review, 3(10), 2834-2840.

Zaid, A., \& De Wet, P. F. (1999) Chapter I Botanical and Systematic Description of Date Palm. FAO Plant Production and Protection Papers, 1-28.

\section{Copyrights}

Copyright for this article is retained by the author(s), with first publication rights granted to the journal.

This is an open-access article distributed under the terms and conditions of the Creative Commons Attribution license (http://creativecommons.org/licenses/by/4.0/). 